\title{
Diktaturets idéhistorie
}

Carl Schmitt:

Dictatorship

Polity Press, 2014

288 sider, $18 \mathrm{f}$.

Carl Schmitts Die Diktatur, som udkom for første gang i 1921, er her knap 100 år efter langt om længe udkommet i engelsk oversættelse. Bogen må anses for at være en hjørnesten i Schmitts forfatterskab og er givetvis hans mest grundige akademiske værk (der er 80 siders noter og henvisninger til en tekst på 225 sider). Det er bl.a. her, man finder en grundig udredning af, hvorfor suverænen kan defineres, som værende "dén, der bestemmer over undtagelsestilstanden", ligesom det er her, man finder en faktisk anvendelse af Schmitts idé om en "begrebernes sociologi." Det er også her, man finder den måske vigtigste forløber til begrebshistorien (Koselleck var elev af Schmitt). Men først og fremmest er bogen en idéhistorisk og juridisk-politisk-filosofisk diskussion af diktatur-begrebet - dets funktion i forskellige juridiske teorier og i afgørende historiske begivenheder som Trediveårskrigen (1618-48), De Engelske Borgerkrige (1642-51) og Den Franske Revolution og dens efterspil (1789-...). Schmitt begrænser sig altså ikke som sådan til begrebet selv, men forfølger snarere den idé eller den quasi-juridiske funktion, som begrebet henviser til.

Schmitts overordnede argument hviler på en overordnet faseinddeling, der afspejles i bogens kapitler. Ifølge Schmitt er der en overgang fra det såkaldte "kommissariske diktatur" til et "suverænt diktatur" og videre til den moderne "undtagelsestilstand." I det kommissariske diktatur er diktatoren en funktionær, der bliver pålagt en opgave af den herskende suveræn, og som til denne opgave får en række undtagelsesmæssige og ekstra-juridiske beføjelser (direkte kontrol over militære enheder, retten til at dømme, ødelægge og slå ihjel, retten til at indkræve skatter osv.). Disse beføjelser tilhører normalt suverænen, men i en presset situation kan suverænen uddelegere midlertidige specialopgaver til en eller flere kom- 
missærer, der ved denne lejlighed får overdraget en række suveræne beføjelser med en ofte nøje beskrevet begrænsning af præcis hvilke beføjelser, der er tale om og hvor og hvornår. Schmitt benytter en lang ekskurs i kapitel 2 på Wallenstein, en böhmisk hertug og general, der under Trediveårskrigen fik en række ekstraordinære beføjelser af den tysk-romerske kejser og som benyttede disse til at udvide sin indflydelse i en sådan grad, at han til sidst de facto kom til at fremstå som noget nær den egentlige suveræn, hvorfor den tyskromerske kejser så sig nødsaget til at få ham fanget "død eller levende" ("død" i dette tilfælde). Det geniale i Schmitts komposition er, at mens kapitel 1 er viet til en teoretisk udredning af diktaturbegrebet og dets funktion - særligt hos Bodin og Machiavelli og til dels dets rødder i romerretten - så er andet kapitel en gennemgang af dets realhistoriske indvirkning i en række forskellige funktioner og begivenheder. Der er på denne måde tale om en "begrebernes sociologi."

Wallenstein er - ligesom Cromwell, der som general under De Engelske Borgerkrige faktisk blev suveræn i England, og som Schmitt også vier en del plads til - udtryk for en glidning i forholdet mellem diktatur og suverænitet. Den diktatoriske magt tilnærmer sig og begynder i stigende grad af tage form af suveræn magt. Dette hænger sammen med en anden bevægelse, som er afgørende for at forstå diktaturbegrebet, og som Schmitt diskuterer tilbagevendende; nemlig centraliseringen af magt i opkomsten af Staten. Det er derfor ikke det tysk-romerske rige med dets væld af fyrstestater og semi-suveræne mellemled (forskellige jurisdiktioner, religiøse institutioner, toldmurer osv.), men derimod det absolutistiske Frankrig, der for alvor markerer overgangen fra det kommissariske diktatur til det suveræne diktatur, og som derfor udgør temaet for kapitel 3. Schmitts tese er her en lille smule provokerende, men langt fra ufornuftig. Ifølge Schmitt, var det absolutistiske Frankrig rent faktisk kendetegnet ved en lang række af mellemled («intermediary powers»), der fungerede som en slags «checks and balances» på det absolutistiske monarki. Det er især i dette lys, siger Schmitt, at man skal læse Montesquieu. Montesquieus magtdelingsteori er i tråd med en absolutistisk suveræn, der kan holdes fra despotisk exces gennem et sindrigt system af parlements (lokale stænderforsamlinger), rådgivende organer, domstole osv. Rousseau, derimod, 
byggede i høj grad sin politiske teori på Montesquieu, men bypassede systemet af checks and balances til fordel for en direkte udøvelse af folkets suverænitet. En slags "absolut demokrati" kunne man sige. Disse to tænkere, Montesquieu og Rousseau, kan i en kontekst af fransk politisk tænkning i 1700-tallet i høj grad ses som den moderne stats faddere. Den absolutte og centraliserede stat - i den ene eller anden model - stammer herfra. Da man importerede Montesquieu til Nordamerika efter Den amerikanske revolution fik man absolutismen med, og da man forsøgte at implementere Rousseaus egalitære idéer i Den franske revolution, fik man paradoksalt nok skabt en koncentration af magten i Staten og dermed fuldbyrdet det absolutistiske projekt, som Kardinal Richelieu igangsatte i starten af 1600-tallet.

Det er fra dette perspektiv, at Schmitt i kapitel 4 og 5 vender sig mod Den franske revolution og det "suveræne diktatur." Ligesom med kapitel 2 i forhold til kapitel 1 er kapitel 4 og 5 en slags historisk sociologi over de begrebsvindinger, der blev skitseret i kapitel 3. Med koncentrationen af magten i Staten bliver staten selv i stigende grad kampplads for politiske overbevisninger. Med Staten kan man nu gøre rigtigt meget og uden Staten meget lidt. Den franske revolution blev hurtigt opfattet som en slags borgerkrig og den konstitutionelt-monarkiske regering efter 1789 indførte derfor en militær undtagelsestilstand (loi martiale), som gav beføjelser til at føre en slags lavintensiv krig mod Frankrigs egen befolkning, eller, set fra de konstitutionelle monarkisters synspunkt, mod den politiske ordens og franske befolknings fjender. Staten havde med andre ord engageret sig i en krig af politisk ideologisk karakter og den form, som denne krig antog, er "undtagelsen" med undtagelseslovgivning og geografiske eller institutionelt afgrænsede områder for denne undtagelse. Med republikanernes magtovertagelse efter revolution 10. august $1792 \mathrm{blev}$ situationen yderligere intensiveret samtidig med, at statsapparatet skiftede hænder. Den indre borgerkrig og den ydre krig mod Europas aristokrater blev videreført med en nyopfindelse, Revolutionsregeringen, der var et decideret "suverænt diktatur": Et organ til at dirigere tropperne i den politiske krig indtil den nye politiske orden kunne stabiliseres i tilstrækkelig grad til at sætte forfatningen i kraft (1793-Forfatningen, på mange måder historiens mest egalitære, trådte aldrig $\mathrm{i}$ kraft, da den grundet 
den indre og ydre krig blev midlertidigt suspenderet). Det suveræne diktatur er med andre ord en administrativ overgangsregering $i$ en revolutionær situation. Det er ikke indkaldt udefra eller på bestemt tid, men indsætter så at sige sig selv og bestemmer derfor selv, hvornår tiden er inde til at overgå til normal forfatningsmæssig regering. Revolutionsregeringen er gældende indtil freds tid, som Saint-Just formulerede det. Det suveræne dikatur adskiller sig fra det kommissariske ved at være selvudnævnt, ved ikke at være tidsligt begrænset og ved selv at udpege både sine opgaver og midler. Men det er også væsentligt at forstå, og Schmitt understreger denne pointe igen og igen, at ethvert diktatur har et (politisk) formål, som er noget andet end dets selvopretholdelse, og derved adskiller det sig fra både despoti og politistat.

Efter Robespierres fald i 1794, som gav plads til en lang serie af reaktionære og i stigende grad autoritære regeringer (Direktoratet 1795, Fructidor 1797, Napoloen 1799, Restaurationen 1814/15), indgår det diktatoriske element i stigende grad som en del af almindelig regeringspraksis. Lokale og midlertidige undtagelsestilstande udråbes for at knuse politiske fjender. Den militære eller ydre undtagelsestilstand (hvor den bevæbnede fjende står for døren) suppleres med den politiske eller fiktive undtagelsestilstand (den indre fjende, der, som vi alle ved, kan gemme sig overalt og måske endda i os selv). Udviklingen, især i fransk retspraksis, udgør temaet for kapitel 6, mens bogen afsluttes med et appendiks om den efterhånden famøse Artikel 48 i Weimarforfatningen af 1919. Dermed er Staten på en gang blevet middel og kampområde for forskellige politiske interesser og ideologier. Det er i den sammenhæng, at "suveræn er dén, der bestemmer over undtagelsestilstanden." Så længe man kan definere undtagelsestilstanden, kan man mobilisere hele statsapparatet i den (latente) politiske borgerkrig, som udkæmpes indenfor statens område.

Schmitts bog har siden fået enorm indflydelse, senest med den italienske filosof Giorgio Agambens teori om det moderne regeringsparadigme som undtagelsestilstand (om han har blødt lidt op på denne tese for nyligt, se "For a Theory of Destituent Power"), men også mere generelt i Agambens figurer som "homo sacer" og funktionæren, der forvalter loven, som præsten eller englen forvalter Guds almene love (se The Kingdom and the Glory og Opus Deı), som 
tydeligvis er inspireret af Schmitts sociologiske læsninger af diktaturets og undtagelsestilstandens sociologiske effekter. Dictatorship er med andre ord aktuel som en analyse af staten, undtagelsen og deres idéhistoriske roller, der både kan belyse nu- og fortid. Bogen er næsten 100 år gammel, og Schmitt er et barn af sin tid, blandt andet når han - utvivlsomt på baggrund af Oktoberrevolutionen 1917 og den fejlslagne kommunistiske tyske revolution 1918-19 ser Staten som et våben i den politiske kamp, der var temmelig ophedet på dette tidspunkt. Men måske er det netop dette, vi har brug for igen at forstå i dag, og her er Schmitts idéhistoriske analyse af diktaturet et væsentligt bidrag.

Nicolai von Eggers 